\title{
Current Distribution Control Method \\ in Anode and Cathode Joints \\ of Aluminum Electrolytic Cells
}

Victor P. Ten, Aleksander I. Gromyko* and Igor E. Nefedov Siberian Federal University 79 Svobodny, Krasnoyarsk, 660041, Russia

Received 02.02.2015, received in revised form 19.03.2015, accepted 29.03.2015

The article describes the current distribution control method in anode and cathode joints of aluminum electrolytic cells. The experimental results of the proposed method on the example of aluminum electrolytic cells Soderberg.

Keywords: current distribution, control, aluminum electrolytic cells.

\section{Способ контроля токораспределения}

\section{в анодном и катодном узлах}

алюминиевых электролизеров

В.П. Тен, А.И. Громыко, И.Е. Нефедов Сибирский федеральный университет Россия, 660041, Красноярск, Свободный, 79

В статье рассмотрен способ контроля токораспределения в анодном и катодном узлах алюминиевых электролизеров. Приведены результаты экспериментальных исследований предложенного способа на примере электролизеров Содерберга.

Ключевые слова: токораспределение, контроль, алюминиевый электролизер.

\section{Введение}

Одной из нерешенных до настоящего времени задач диагностики эффективности процесса электролиза алюминия является контроль токораспределения по штырям самообжигающегося анода и катодным блюмсам электролизера.

(c) Siberian Federal University. All rights reserved

* Corresponding author E-mail address: aig0309@yandex.ru 
Отсутствие приемлемых для производства средств контроля токораспределения в анодном узле создает значительные сложности в разработке оптимальных алгоритмов перестановки штырей или схем замены анодов, что отрицательно сказывается на стабильности технологического процесса электролиза алюминия.

Для катодного узла актуально своевременное определение мест протечки металла и разрушений подины. Устранение технологических отклонений в работе катодного узла позволяет увеличить сроки службы электролизной ванны.

\section{Нарушения в работе анодов}

В $[1,2]$ рассмотрены основные нарушения в работе самообжигающихся анодов с верхним токоподводом и меры по их предотвращению и ликвидации. На рис. 1 упрощенно показаны типичные дефекты в анодном блоке: 1 - ослабление контакта штыря с анодной шиной; 2 - закупоривание анодной массой подштыревого отверстия; 3 - перегрев анода; 4 - припекание анодной массы к анодному кожуху; 5 - припекание анода к анодному кожуху; 6 - каверны в аноде; 7 - протекание массы на подошву через подштыревое отверстие; 8 - конус на подошве анода; 9 - углубления в аноде; 10 - шейки на боковой поверхности анода; 11 - горизонтальные трещины в теле анода; 12 - неровности на поверхности штырей.

Указанные отклонения сопровождаются образованием сквозных отверстий в теле анода, частичной пассивацией, перегревом отдельных штырей, локальным изменением межполюсного расстояния, переходом металла в нестабильное состояние и, как следствие, приводят к перераспределению тока по штырям. В результате происходит нарушение теплового режима ванны и уменьшение выхода по току.

В работе [3] даны количественные оценки зависимости выхода по току от величины коэффициента токораспределения. Так, при изменении коэффициента токораспределения $\mathrm{K}_{\text {тр }}(0,7-$ 2,6) выход по току варьируется в пределах от 93 до 73,5 \%.

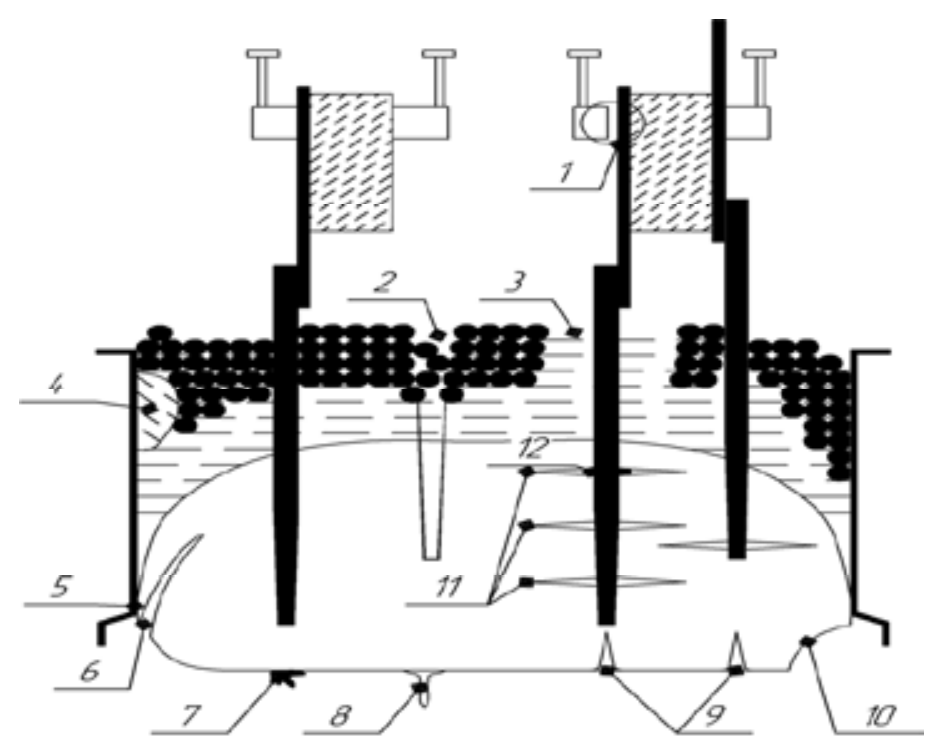

Рис. 1. Нарушения в работе анодов 
Современные тенденции к увеличению силы тока серии вызывают существенные искривления и волнения поверхности металла, что также негативно сказывается на работе анодного узла.

В катодном узле неравномерность токораспределения по блюмсам может привести к деформациям и разрушению подины и к прорыву расплава.

Уоказанные нарушения подчеркивают важность и своевременность контроля токораспределения в анодном и катодном узлах электролизера.

\section{Методы контроля токораспределения}

Для количественной оценки неравномерности токораспределения по анодам электролизера используют [3-5] среднеквадратическое отклонение, степень перегрузки каждого штыря, коэффициенты перегрузки, таблицы (номограммы) распределения тока по штырям.

Измеряемыми параметрами для оценок принимаются: токовая нагрузка на каждом штыре; средняя сила тока по штырям, фактический ток серии. Заданные параметры: номинальная сила тока по штырям, номинальный ток серии электролизеров.

В настоящее время на производстве контроль распределения тока по анодным штырям преимущественно осуществляют методом «вилки» и с помощью токоизмерительных клещей типа КЭИ-5 на основе датчика Холла с диапазоном измерения от 0 до 5000 ампер. В обоих случаях процесс измерения продолжительный и трудоемкий, кроме того, измерения токовыми клещами в штырях, прилегающих к торцам анода, дают значительную погрешность из-за влияния тока в анодных спусках.

Погрешность измерения методом «Вилки» обусловлена плохим контактом щупа с боковой поверхностью штыря-штанги и малым сопротивлением участка цепи, на котором измеряется падение напряжения, пропорциональное определяемому току в штыре.

\section{Способ контроля токораспределения в анодном и катодном узлах алюминиевых электролизеров}

Авторами предложен способ и устройство реализации контроля токораспределения по анодным штырям и блюмсам с использованием гармоник тока серии электролизеров [6-8].

Рассмотрим возможность применения гармоник тока серии для контроля распределения тока по анодным штырям.

Для питания электролизеров типа С-8БМ используют 6-фазные мостовые выпрямители [9]. Схема состоит из двух параллельно соединенных 3-фазных выпрямителей, силовые трансформаторы которых включены «звездой» и «треугольником», в результате чего на выходе преобразователя возникают пульсации тока серии.

Пульсации результирующего напряжения тока серии существенно отличаются от импульсов косинусоидальной формы. Такое искажение импульсов способствует увеличению числа гармоник в спектре.

В работе [9] исследованы амплитудно-частотные характеристики тока серии промышленных электролизеров.

Энергетический спектр напряжения тока серии, рассчитанный для случая нагрузки выпрямителя тока серии на активное сопротивление, т.е. для сигнала с косинусоидальной оги-

$$
-449-
$$


бающей, представлен на рис. 2. Для сравнения на рис. 3 приведен экспериментально снятый график спектральной плотности напряжения серии электролизеров. Как видим, в области нижних частот спектры совпадают.

Наибольшей амплитудой в спектре обладает гармоническая составляющая с частотой 600 Гц.

При чисто активной нагрузке и шестифазном двухполупериодном выпрямлении тока уровень пульсаций достигает 3 \% от величины выпрямленного значения. Активно-индуктивное сопротивление ошиновки серии электролизеров снижает уровень пульсаций. Так, на частоте 600 Гц уровень пульсаций тока составляет 1-30 ампер для каждого штыря или блюмса.

В соответствии с ГОСТ 13109-97 нормально допустимые отклонения частоты 600 Гц будут находиться в пределах +/- 2,4 Гц. Приведенные данные показывают, что в качестве информативного параметра для контроля токораспределения возможно использовать гармоническую составляющую частотой 600 Гц.

В предлагаемом способе силу тока измеряют с помощью индукционных датчиков, устанавливаемых на каждый токоподводящий и/или токоотводящий элемент электролизера.

Затем определяют суммарный сигнал от всех измеренных элементов и находят коэффициент пропорциональности путем деления силы тока серии, измеренной на момент съема сигна-

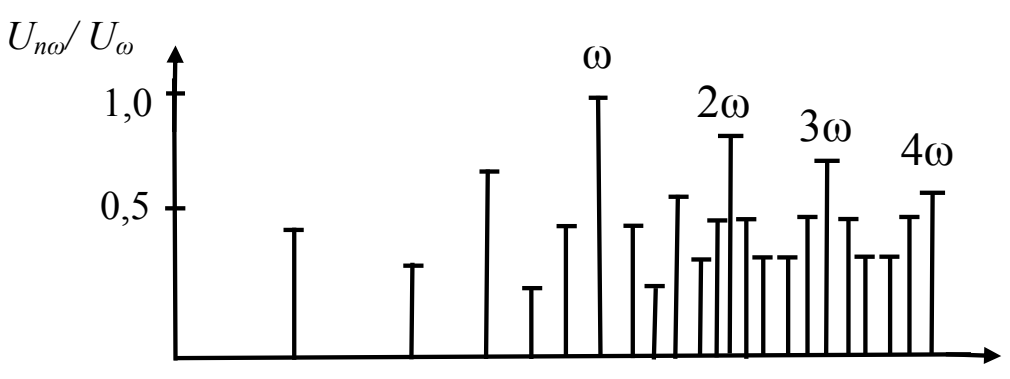

$\omega$

Рис. 2. Расчетные значения спектральных составляющих энергетического спектра на выходе выпрямительных агрегатов

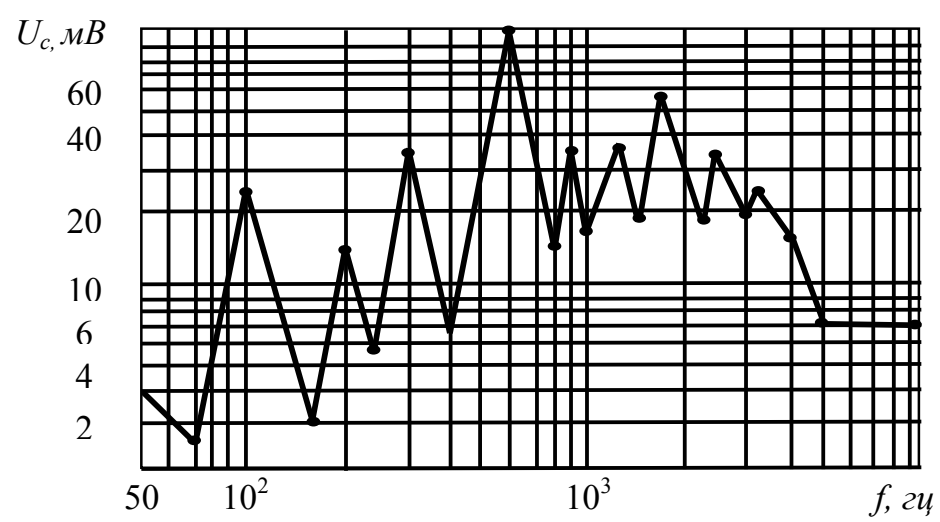

Рис. 3. Экспериментально снятые характеристики энергетического спектра тока серии

$$
-450-
$$


лов с датчика, на суммарный сигнал и с учетом коэффициента пропорциональности находится величина силы тока в каждом токоподводящем и/или токоотводящем элементе электролизера. Полученные значения кодируют и передают по линии связи в АСУ для принятия необходимых технологических воздействий.

Для реализации способа авторами разработано устройство контроля токораспределения [7] и проведены экспериментальные исследования в условиях электролизного цеха.

На рис. 4 представлена функциональная схема устройства, реализующего предлагаемый способ контроля токораспределения по токоподводящим элементам конструкции анодного узла электролизера с самообжигающимися анодами.

Введены следующие обозначения: $\mathrm{X}_{1} \ldots . \mathrm{X}_{\mathrm{n}}$ - клеммы на входе коммутатора для подключения датчиков тока, 1 - анодная шина, 2 - анодный штырь, 3 - электромагнитные датчики, 4 - линии связи электромагнитных датчиков (3) с коммутатором входных сигналов (7), 5 - швеллер, 6 - скоба крепления швеллера (5) к анодной шине, 7 - коммутатор входных сигналов, 8 - нормализатор входных сигналов, 9 - АЦП, 10 - микропроцессор, 11 - устройство согласования, 12 - автоматизированная система управления (АСУ), 13 - алюминиевые штанги, подводящие ток к штырям, 14 - элемент крепления скобы (6).

Устройство контроля токораспределения в анодном узле алюминиевого электролизера работает следующим образом.

Сигналы с выхода электромагнитных датчиков (3), пропорциональные силе тока в каждом из анодных штырей (2), подаются на коммутатор входных сигналов (7) через линии связи (4) электромагнитных датчиков (3) с коммутатором входных сигналов (7). Линии связи (4) в виде витых пар и электромагнитные датчики (3) устанавливают внутри швеллера (5) до его монтажа на анодной шине (1). Электромагнитные датчики располагают ниже анодной шины по центру плоскости алюминиевых штанг (2), подводящих ток к штырям. Швеллер (5) крепят к анодной

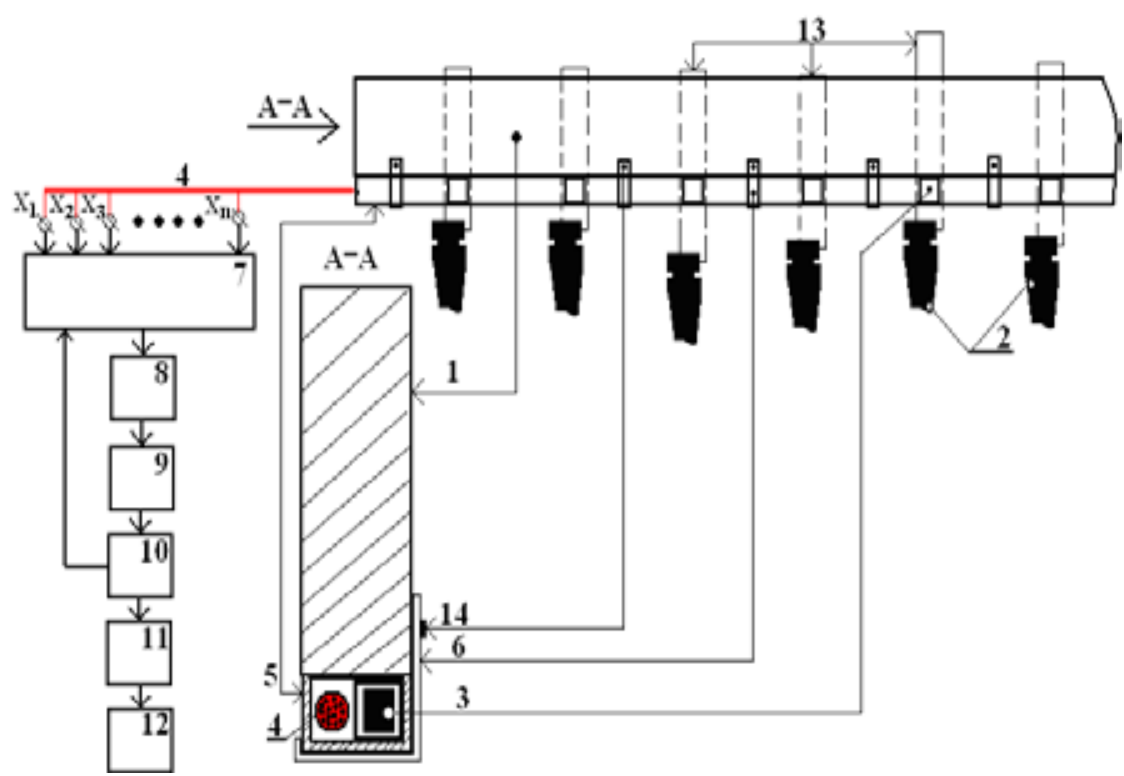

Рис. 4. Устройство контроля токораспределения в анодном узле алюминиевых электролизеров

$$
-451-
$$


шине (1) скобами (6), используя элемент крепления (11). Ширину швеллера (5) берут равной толщине анодной шины (1), что обеспечивает защиту электромагнитных датчиков от механического повреждения и воздействия выбросов огня при смене штырей. Сила тока в каждом из анодных штырей (2), а следовательно, и в каждой штанге (13), подводящей ток к штырю, зависит от сопротивления контакта алюминиевой штанги (13) с анодной шиной (1) и сопротивления контакта (глубины погружения) анодного штыря с углеродистым телом анода.

С выхода коммутатора входных сигналов (7) сигналы, пропорциональные току в каждом из анодных штырей (2), поступают на вход нормализатора входных сигналов (8), где обеспечивают необходимую фильтрацию и согласование по уровню. С выхода нормализатора (8) сигналы подают на АЦП (9) для преобразования в цифровой код.

Преобразованный в АЦП (9) цифровой сигнал подают на микропроцессор (10), где рассчитывают ток, протекающий через каждый анодный штырь (2), и данные передают через устройство согласования (11) на вход АСУ (12). АСУ (12) выводит информацию на дисплей и/или печать в виде номограммы, представленной на рис. 5.

На рис. 6 представлен график экспериментально снятой зависимости действующего значения напряжения гармоники 600 Гц, на выходе индукционного датчика от силы тока, протекающего в проводнике при двухполупериодном шестифазном выпрямлении тока промышленной частоты. График показывает, что сигнал, снимаемый с электромагнитного датчика, имеет линейную зависимость от силы тока.

На рис. 7 изображена экспериментально измеренная форма сигнала на выходе индукционного датчика одного из штырей.

В [10] авторами изложен переносной вариант реализации разработанного способа контроля токораспределения. Данное устройство позволяет проводить экспресс-контроль по отдельным токоподводящим и токоотводящим элементам электролизера.

На рис. 8 приведены графики сравнительных результатов измерений методом «вилки» и переносным прибором с индукционным преобразователем по каждому из четырех рядов (А, B, C, D) токоподводящих штырей анодного узла электролизера Содерберга.

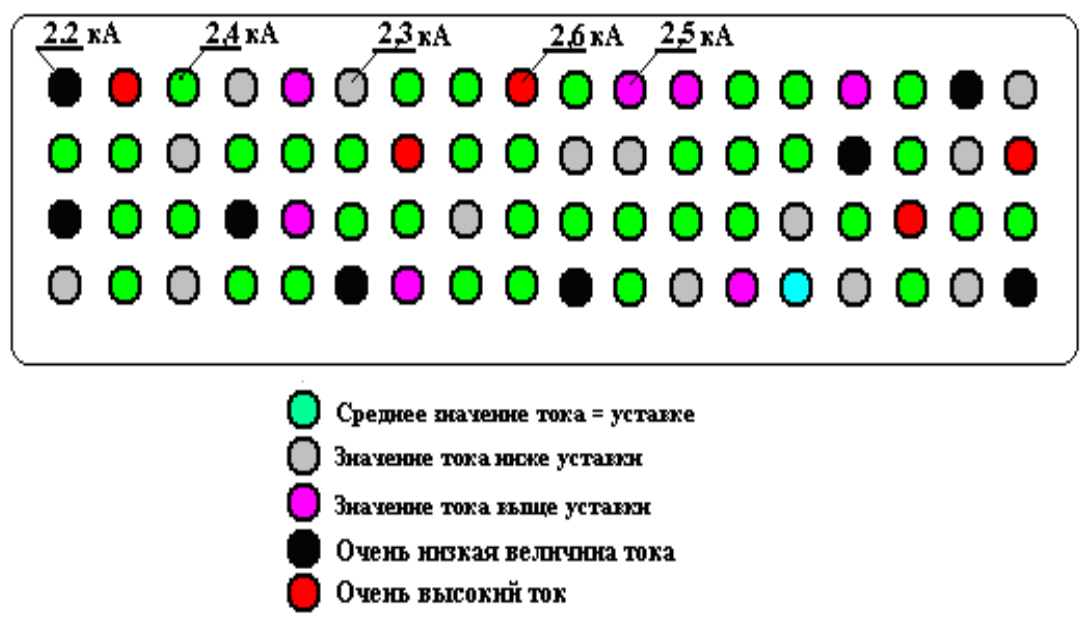

Рис. 5. Вариант вывода информации на дисплей и печать АСУ 


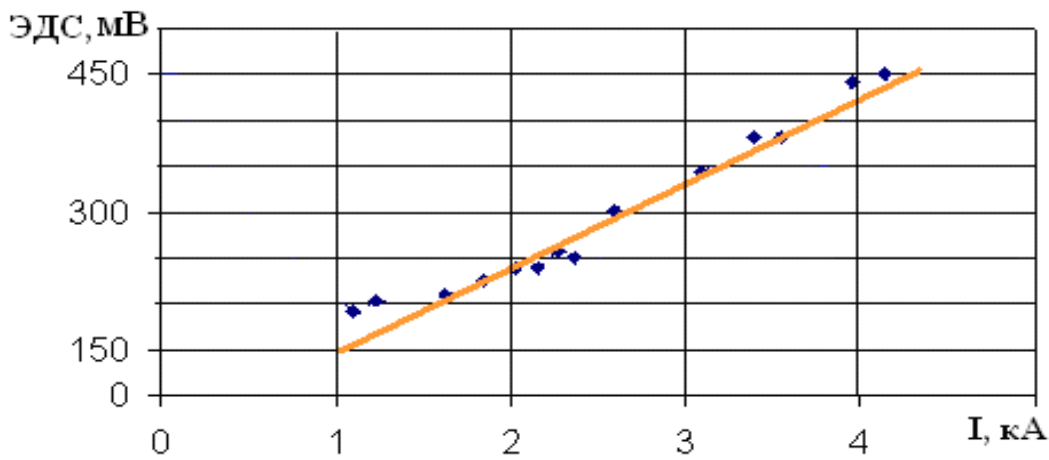

Рис. 6. Зависимость действующего значения напряжения гармоники 600 Гц на выходе индукционного датчика

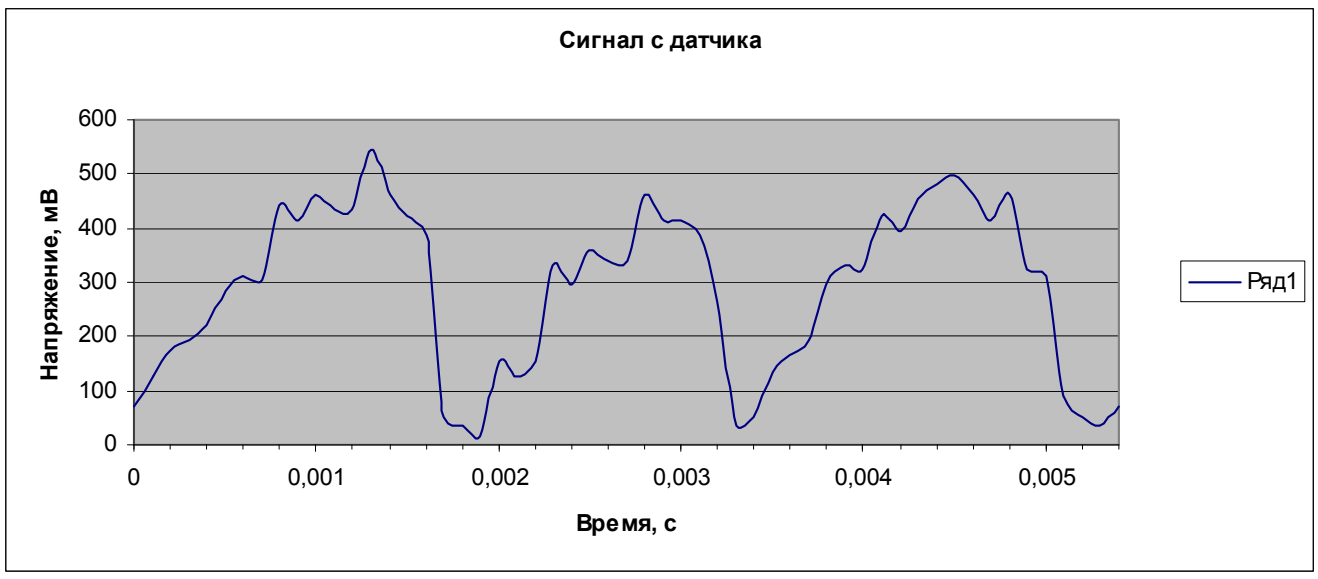

Рис. 7. Форма сигнала на выходе индукционного датчика на центральной частоте 600 Гц

По результатам обработки экспериментальных данных определены средние значения ( $\left.\mathrm{I}_{\mathrm{CP}}\right)$ и среднеквадратичные отклонения $\left(\mathrm{I}_{\mathrm{CP} . к \mathrm{~B}}\right)$ силы тока по парным рядам $(\mathrm{A}, \mathrm{B})$ и $(\mathrm{C}, \mathrm{D})$ для двух методов измерения (табл. 1).

С помощью переносного устройства время измерения величины тока на всех 72 штырях анода составляет 10-15 мин. Это дает возможность своевременно оценить качество проводимых технологических работ и устранить нарушения в процессе обслуживания.

\section{Выводы}

Положительный эффект от реализации данного способа контроля токораспределения по анодным штырям и блюмсам заключается в стабилизации технологического режима процесса электролиза, снижении потерь электроэнергии в анодном и катодном узлах за счет своевременного устранения перекосов в распределении электрического тока.

С помощью разработанных электромагнитных датчиков впервые удалось реализовать бесконтактный метод измерения величины тока в штырях, расположенных с торцов анода вблизи анодных спусков. 

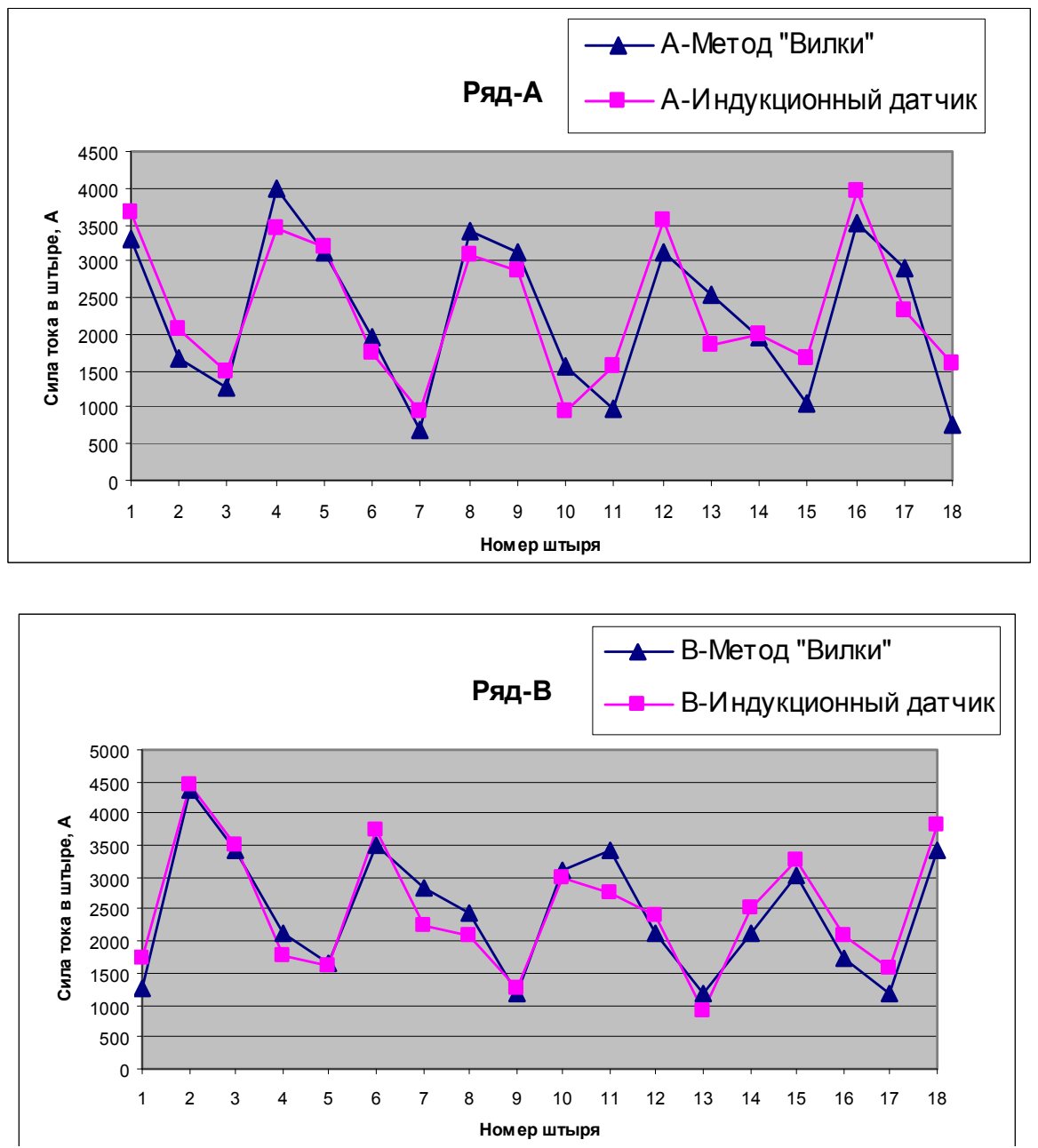

Рис. 8. Графики сравнительных результатов измерений методом «вилки» и переносным прибором с индукционным преобразователем (измерения выполнены на ОАО «КрАЗ», корпус 3, электролизер № 311)

Таблица 1

\begin{tabular}{|c|c|c|c|c|}
\hline \multirow{2}{*}{} & \multicolumn{2}{|c|}{ Метод «вилки» } & \multicolumn{2}{c|}{ Индукционный датчик } \\
\cline { 2 - 5 } & Ряды штырей (A,B) & Ряды штырей (C,D) & Ряды штырей (A,B) & Ряды штырей (C,D) \\
\hline $\mathrm{I}_{\mathrm{CP}, \mathrm{A}}$ & 2359,79 & 2465,21 & 2410,98 & 2414,02 \\
\hline $\mathrm{I}_{\text {СР.кв, } \mathrm{A}}$ & 1013,52 & 1023,51 & 956,67 & 918,46 \\
\hline Ток серии, А & \multicolumn{3}{|c|}{173700} \\
\hline
\end{tabular}



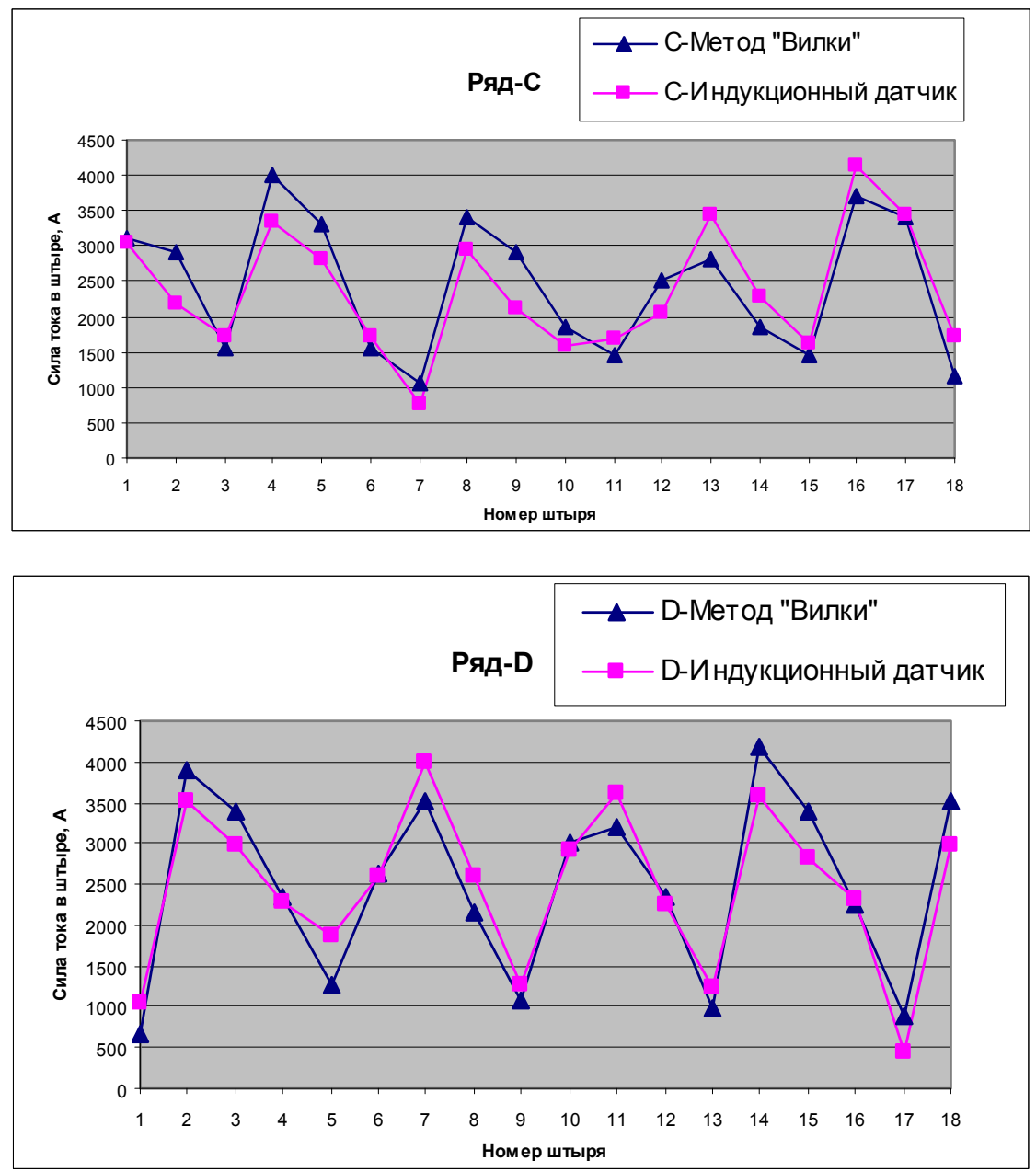

Рис. 8. Графики сравнительных результатов измерений методом «вилки» и переносным прибором с индукционным преобразователем (измерения выполнены на ОАО «КрАЗ», корпус 3, электролизер № 311)

Использование электромагнитного датчика позволяет с приемлемой для технологического процесса погрешностью измерять величину силы тока в каждом токоподводящем и токоотводящем элементе электролизера и решить задачу по обеспечению равномерного распределения тока по телу анода, контролировать неравномерность токораспределения по блюмсам катодного узла и, как следствие, устранить ряд технологических нарушений процесса электролиза алюминия, увеличить сроки эксплуатации электролизной ванны.

\section{Список литературы}

[1] Борисоглебский Ю.В., Галевский Г.В., Кулагин Н.М. и др. Металлургия алюминия. Новосибирск: Наука, 1999. 438 с.

[2] Минцис М.Я., Крюковский В.А., Галевский Г.В. // Цветные металлы и минералы: Сб. докладов VI Международного конгресса. Красноярск, 2014. С. 396-401. 
[3] Калужский Н.А., Слуикий И.З., Сквориов А.П. и др. Повышение эффективности электролитического производства алюминия. Л., 1985. 130 с.

[4] Баженов А.Е., Венков Г.А., Петров Д.С. // Цветные металлы. 1984. № 3. С. 47-49.

[5] Громыко А.И., Соболев А.Н, Тен В.П. // Свид. о рег. программы для ЭВМ № 2011615948, (2011).

[6] Громыко А.И., Ситников А.М. Пат. 2371524 (2009) РФ // Б. И. 2009. № 30.

[7] Громыко А.И., Никитин Ю.И., Тен В.П. и др. Пат. 2401325 (2010) РФ // Б. И. 2010. № 28.

[8] Громыко А.И., Гнитиев В.П., Матюшев Р.А., Тен В.П. Свид. о рег. программы для ЭВМ № 2011610050, (2011).

[9] Громыко А.И., Шайдуров Г.Я. Автоматический контроль технологических параметров алюминиевых электролизеров. Красноярск: Изд-во КГУ, 1984. 240 с.

[10] Громыко А.И., Нефедов И.Е., Тен В.П. Пат. 2484183 (2013) РФ // Б. И. 2013. № 16. 